\title{
Zinc Loss in Sweat of Athletes Exercising in Hot and Neutral Temperatures
}

\author{
Kevin Tipton, Nancy R. Green, \\ Emily M. Haymes, and Mary Waller
}

Zinc $(\mathrm{Zn})$ loss from sweat of 9 male and 9 female athletes exercising under hot $\left(35^{\circ} \mathrm{C}, \mathrm{HE}\right)$ and neutral $\left(25^{\circ} \mathrm{C}, \mathrm{NE}\right)$ conditions was examined. Subjects exercised at $50 \% \mathrm{VO}_{2} \max$ on a cycle ergometer for $1 \mathrm{hr}$ during each trial. Cell-free sweat samples were analyzed for $\mathrm{Zn}$ by atomic absorption spectrophotometry. There was a significant interaction of time, gender, and temperature for whole-body sweat rates (WBSR). WBSR for males were higher during both trials and at each time. WBSR from the second half of exercise were higher than those from the first half for both sexes and temperature conditions. Sweat $\mathrm{Zn}$ concentration was higher in the NE than in the HE, but when the sweat rates were included, the rate of $\mathrm{Zn}$ loss was no different between $\mathrm{HE}$ and NE. $\mathrm{Zn}$ concentration of the sweat for the first half of exercise was over twice that of the second half. Sweat $\mathrm{Zn}$ concentration of the men was no different than that of the women; however, due to greater sweat rate, men had significantly higher $\mathrm{Zn}$ losses. Although total $\mathrm{Zn}$ losses are estimated to be relatively low compared to the RDA, exercise at moderate intensities may increase surface $\mathrm{Zn}$ losses.

Key Words: zinc, exercise, sweat, heat

Zinc $(\mathrm{Zn})$ is an important trace mineral in human metabolism. It serves as a cofactor for up to 100 enzymes, including superoxide dismutase, alkaline phosphatase, and alcohol dehydrogenase (26). Adequate $\mathrm{Zn}$ nutriture for athletes may be especially important since it is a cofactor for enzymes such as AMPdeaminase (26) and carbonic anhydrase (14), all important enzymes for exercise metabolism.

Serum $\mathrm{Zn}$ of athletes has been found to be significantly reduced when compared to nonathletes $(9,11)$. Several mechanisms have been suggested to account for this difference. Athletes may be consuming a diet that is low in $\mathrm{Zn}$ $(8,24)$ or have increased metabolic demands, which would increase the need for $\mathrm{Zn}$. Alternatively, $\mathrm{Zn}$ losses in athletes may be greater than in nonathletes. $\mathrm{Zn}$ is lost in urine $(1,18)$ and sweat $(2)$ during exercise. Since training increases

Tipton and Green are with the Department of Nutrition and Food Science, Auburn University, Auburn, AL 36849. Haymes and Waller are with the Department of Nutrition, Food and Movement Sciences, Florida State University, Tallahassee, FL 32306. 
sweat rate (20), athletes may have higher zinc losses associated with higher sweat losses. Very few studies have examined $\mathrm{Zn}$ losses in the sweat of exercising subjects $(2,5)$.

Increased sweat rates during exercise at high temperatures (19) may further exacerbate $\mathrm{Zn}$ losses. Consolazio et al. (5) reported mineral losses, including $\mathrm{Zn}$, of subjects in the heat over a 7.5 -hr period that included $30 \mathrm{~min}$ of light exercise. To our knowledge, this is the only report of $\mathrm{Zn}$ losses during exercise in the heat, although there are several reports of sweat $\mathrm{Zn}$ losses from resting subjects under hot conditions $(12,13,23,25)$. The purpose of this study was to examine $\mathrm{Zn}$ loss from the sweat of both male and female athletes exercising under hot and neutral conditions.

\section{Methods}

The subjects for the study were 9 male and 9 female trained volunteers. Each was informed of the methods and possible risks of the study and signed an institutionally approved informed consent form. The study was designed so that each subject exercised for 1 hour in both a hot and a neutral environment. Dependent variables measured were sweat rate, $\mathrm{Zn}$ concentration in sweat, rectal temperature, and heart rate. Physical characteristics for the subjects are given in Table 1. Prior to testing, maximum $\mathrm{O}_{2}$ consumption $\left(\mathrm{VO}_{2} \mathrm{max}\right)$ was measured using a continuous protocol on a Monark cycle ergometer (16). Subjects pedaled using progressively increasing workloads until $\mathrm{VO}_{2} \max$ was reached. Criteria for $\mathrm{VO}_{2} \mathrm{max}$ were (a) differences in $\mathrm{VO}_{2}$ values of less than $150 \mathrm{ml} / \mathrm{min}$ for two consecutive workloads, (b) RER values $>1.1$, and (c) heart rate within 10 beats of age-predicted maximum.

The subjects exercised at $50 \%$ of their predetermined $\mathrm{VO}_{2} \max$ on a cycle ergometer for $1 \mathrm{hr}$ during each of two trials. The hot exercise (HE) trial was performed at $35^{\circ} \mathrm{C}$ and the neutral exercise (NE) trial at $25^{\circ} \mathrm{C}$. Relative humidity was similar for both and ranged from 70 to $75 \%$. Air velocity was not recorded. Trials were performed in a randomly selected order and a minimum of 7 days separated each trial. Rectal temperature and heart rate were monitored throughout each trial.

Whole-body sweat rates were determined by measuring weight changes.

Table 1

Physical Characteristics of 9 Male and 9 Female Athletes

\begin{tabular}{lrrrrr}
\hline & \multicolumn{2}{c}{ Males } & & \multicolumn{2}{c}{ Females } \\
\cline { 3 - 3 } \cline { 5 - 6 } & Mean & $S D$ & & Mean & $S D$ \\
\hline Age $(\mathrm{yrs})$ & 27.3 & 3.54 & & 28.7 & 3.32 \\
$\mathrm{Ht}(\mathrm{cm})$ & 178.0 & 8.98 & & 164.0 & 4.59 \\
$\mathrm{Wt}(\mathrm{kg})$ & 72.7 & 8.73 & & 57.2 & 4.79 \\
$\mathrm{VO}_{2}$ max $(\mathrm{ml} / \mathrm{kg} / \mathrm{min})$ & 62.2 & 9.57 & & 47.7 & 6.35 \\
& & & & \\
\hline
\end{tabular}


Weights were measured prior to, at 30 min of, and immediately after each trial. After being dried with a towel, subjects were weighed wearing shorts only (males) or shorts and jog bras (females). Fluid intake was monitored during the exercise periods and whole-body sweat rates were calculated from the weight changes adjusted for fluid intakes.

Sweat was collected in polyethylene arm bags twice during the $\mathrm{HE}$ and NE trials from a randomly assigned arm for each subject. The subjects thoroughly cleaned the arm with soap and water, and the arm was thoroughly rinsed with deionized water prior to arm bag placement. The arm bag was fitted over the entire arm and secured with an elastic band at the deltoid tuberosity. The band was not tight enough to restrict blood flow. Arm bags have been shown to decrease sweat rate on enclosed arms, but sweat suppression does not occur until the second hour of sweating (4). The arm bag was in place at least 15 min during the first and second $30 \mathrm{~min}$ of each exercise bout, or until at least $10 \mathrm{ml}$ of sweat was collected. Suppression of sweating was assumed to be negligible since the arm bags were on the arms for short intervals and the total exercise time was only 1 hour.

The arm bags were punctured and the sweat was drained into acid washed tubes. The sweat samples were centrifuged at 3,500 rpm for $15 \mathrm{~min}$ in a TRIAC centrifuge to separate the majority of the skin cells from the sweat. The supernatant was then drawn off with a pasteur pipette and filtered through a $2.7-\mu \mathrm{m}$ Whatman 50 filter. The samples were then frozen at $-20^{\circ} \mathrm{C}$ until analysis for $\mathrm{Zn}$ content. For $\mathrm{Zn}$ determination, the cell-free sweat samples were thawed and analyzed by atomic absorption spectrophotometry with a Perkin-Elmer model 3100 atomic absorption spectrophotometer (wavelength $23.9 \mathrm{~nm}$, slit width $0.7 \mathrm{~nm}$ ). Calculation of the standard curve was performed using Perkin-Elmer standard $\mathrm{Zn}$ solution. Recovery of $\mathrm{Zn}$ from spiked samples was $97.4 \%$. Sterile new polyethylene arm bags were used for each sample. A blank of distilled water was analyzed using the same procedures as for the sweat samples and there was no evidence of trace minerals.

Dietary $\mathrm{Zn}$ intake was estimated from 3-day dietary records and calculated by Food Processor II ${ }^{\circledR}$ diet analysis program. Eight of the 18 subjects, 5 males and 3 females, completed and returned the dietary records.

Whole-body $\mathrm{Zn}$ loss was estimated by multiplying $\mathrm{Zn}$ concentrations from arm sweat by whole-body sweat rates. All data are expressed as mean $\pm S D$. Differences between means were detected by repeated-measures ANOVA. When group means were found to be significantly different, $F$ tests of decreasing cluster sizes were used to determine individual differences. For each group of means, an $F$ statistic was computed. If the $F$ statistic for the largest cluster of means was found to be significant, an $F$ value for the next smallest group was determined. If significance was not found, the calculations were ended. $F$ values for each cluster were determined until no significance was found or two means were compared. This method allowed the minimum significant differences to be detected while minimizing the risk of type II errors. Statistical significance was set at the $p<0.05$ level.

\section{Results}

Table 2 illustrates the whole-body sweat rates $\left(\mathrm{g} / \mathrm{m}^{2} / \mathrm{h}\right)$ of the subjects during cycle ergometer exercise. The interaction effect of temperature, time, and sex was significant. Sweat rates for the final $30 \mathrm{~min}$ were significantly higher than 
Table 2

Whole-Body Sweat Rates for 9 Malle and 9 Female Athletes Exercising on a Cycle Ergometer for $1 \mathrm{hr}$ in Each Environment $\left(\mathrm{g} / \mathrm{m}^{2} / \mathrm{h} \pm \mathrm{SD}\right)$

\begin{tabular}{|c|c|c|c|c|}
\hline & \multicolumn{2}{|c|}{ Hot environment $\left(35^{\circ} \mathrm{C}\right)$} & \multicolumn{2}{|c|}{ Neutral environment $\left(25^{\circ} \mathrm{C}\right)$} \\
\hline & Sweat 1 & Sweat 2 & $\begin{array}{c}\text { Sweat } \\
1\end{array}$ & Sweat 2 \\
\hline Males & $\begin{array}{l}506.05^{\mathrm{b}, \mathrm{c}} \\
\pm 90.37\end{array}$ & $\begin{array}{l}1070.39^{a} \\
\pm 338.13\end{array}$ & $\begin{array}{l}390.94^{\mathrm{C}} \\
\pm 45.84\end{array}$ & $\begin{array}{r}551.48^{b} \\
\pm 123.90\end{array}$ \\
\hline Females & $\begin{array}{l}353.93^{b, c} \\
\pm 41.43\end{array}$ & $\begin{array}{r}629.08^{a} \\
\pm 216.54\end{array}$ & $\begin{array}{l}245.01^{\mathrm{C}} \\
\pm 60.01\end{array}$ & $\begin{array}{l}389.47^{b} \\
\pm 77.77\end{array}$ \\
\hline
\end{tabular}

Note. Sweat 1 is the sweat rate from the sweat sample collected during the first 30 min of exercise, and sweat 2 is the sweat rate collected during the second $30 \mathrm{~min}$.

$a, b, c$ Means in each row with different superscript letters differ significantly, $p<0.05$.

Means of males are significantly different $(p<0.05)$ from means of females for each sample in each environment.

Table 3

Arm Sweat Rates From 9 Male and 9 Female Athletes Exercising on a Cycle Ergometer for $1 \mathrm{hr}$ in Each Environment (ml/min $\pm S D)$

\begin{tabular}{|c|c|c|c|c|c|c|c|c|}
\hline & \multicolumn{4}{|c|}{ Hot environment $\left(35^{\circ} \mathrm{C}\right)$} & \multicolumn{4}{|c|}{ Neutral environment $\left(25^{\circ} \mathrm{C}\right)$} \\
\hline & \multicolumn{2}{|c|}{ Sweat 1} & \multicolumn{2}{|c|}{ Sweat 2} & \multicolumn{2}{|c|}{ Sweat 1} & \multicolumn{2}{|c|}{ Sweat 2} \\
\hline & $M$ & $S D$ & M & $S D$ & M & $S D$ & M & $S D$ \\
\hline Males & 2.51 & 0.78 & 2.24 & 0.71 & 1.38 & 0.55 & 1.45 & 0.43 \\
\hline Females & 1.26 & 0.40 & 1.31 & 0.52 & 0.59 & 0.23 & 0.73 & 0.27 \\
\hline Mean & 1.89 & $0.89^{a}$ & 1.78 & 0.66 & 0.99 & $0.56^{\mathrm{a}}$ & 1.10 & 0.51 \\
\hline
\end{tabular}

Note. Sweat 1 is the sweat rate from the sweat sample collected during the first $30 \mathrm{~min}$ of exercise, and sweat 2 is the sweat rate collected during the second $30 \mathrm{~min}$.

aSignificantly different, $p<0.05$.

those for the first $30 \mathrm{~min}$ for both males and females in both temperature conditions. Sweat rates of males were higher than sweat rates of females for each 30 min period under both $\mathrm{HE}$ and $\mathrm{NE}$. During the last $30 \mathrm{~min}$ of the $\mathrm{HE}$ trial, the sweat rates of both males and females were higher than those in the last $30 \mathrm{~min}$ of the NE trial. However, there were no differences for either sex between the first $30 \mathrm{~min}$ of $\mathrm{HE}$ and $\mathrm{NE}$.

The sweat loss from the arms of the subjects is summarized in Table 3. There were no statistically significant differences in arm sweat rate $(\mathrm{ml} / \mathrm{min})$ for males or females during the $\mathrm{HE}$ or NE trials. A significant interaction was found 
between time and temperature. The arm sweat rate of all subjects combined was higher during $\mathrm{HE}$ than NE. However, only during the initial $30 \mathrm{~min}$ (HE vs. NE) was the difference statistically significant. The sweat rate of males over both trials $(1.90 \pm 1.78 \mathrm{ml} / \mathrm{min})$ was significantly higher than that of females over both trials $(0.97 \pm 0.48 \mathrm{ml} / \mathrm{min})$.

Figure 1 summarizes the $\mathrm{Zn}$ concentration of the sweat and Figure 2 summarizes the $\mathrm{Zn}$ loss per minute for males and females during the two halves of both $\mathrm{HE}$ and $\mathrm{NE}$ trials. Although there was no significant difference in $\mathrm{Zn}$ concentrations due to gender, the data are separated by gender so that comparisons of $\mathrm{Zn}$ loss may be demonstrated more clearly.

There were no significant interaction effects of temperature and time for $\mathrm{Zn}$ concentration in sweat. When the $\mathrm{Zn}$ concentration of the sweat is combined for all subjects and both treatments, $\mathrm{Zn}$ loss in the first $30 \mathrm{~min}(0.97 \pm 0.88 \mu \mathrm{g} /$ $\mathrm{ml})$ was significantly higher than that of the final $30 \mathrm{~min}(0.41 \pm 0.22 \mu \mathrm{g} / \mathrm{ml})$. The $\mathrm{Zn}$ in the sweat of all subjects during both halves of the NE trial was significantly higher than that of the $\mathrm{HE}$ trial $(0.87 \pm 0.87 \mu \mathrm{g} / \mathrm{ml}$ vs. $0.52 \pm 0.41$ $\mu \mathrm{g} / \mathrm{ml})$.

The $\mathrm{Zn}$ loss from arm sweat during the initial $30 \mathrm{~min}(1.11 \pm 0.87 \mu \mathrm{g} / \mathrm{min})$ for all subjects and over both trials combined was significantly higher than that for the final $30 \mathrm{~min}(0.56 \pm 0.38 \mu \mathrm{g} / \mathrm{min})$. Males had a significantly higher $\mathrm{Zn}$ loss from arm sweat $(1.06 \pm 0.84 \mu \mathrm{g} / \mathrm{min})$ than females $(0.61 \pm 0.50 \mu \mathrm{g} / \mathrm{min})$ for both trials and over both halves combined. Whole-body $\mathrm{Zn}$ loss was significantly higher for males $(10.82 \pm 7.79 \mu \mathrm{g} / \mathrm{min})$ than for females $(6.67 \pm 5.05 \mu \mathrm{g} / \mathrm{min})$. When the whole-body $\mathrm{Zn}$ loss was standardized for body surface area, the ANOVA did not reveal any significant differences, although $\mathrm{Zn}$ loss tended to be higher for males $\left(344.53 \pm 265.22 \mu \mathrm{g} / \mathrm{m}^{2} / \mathrm{h}\right)$ than females $(244.74 \pm 178.17 \mu \mathrm{g} /$ $\left.\mathrm{m}^{2} / \mathrm{h}\right)(p<0.10)$. There were no significant differences in $\mathrm{Zn}$ loss from wholebody sweat between the HE and NE environments, the first and second $30 \mathrm{~min}$ of exercise, nor were there any significant interaction effects.

Dietary $\mathrm{Zn}$ intake ranged from 8.1 to $56.4 \mathrm{mg} /$ day $(16.34 \pm 15.22)$ for the 8 subjects, and sweat $\mathrm{Zn}$ concentration ranged from 0.35 to $1.5 \mu \mathrm{g} / \mathrm{ml}$ for these subjects. No correlation was found between the level of $\mathrm{Zn}$ intake and the $\mathrm{Zn}$ concentration in the sweat.

\section{Discussion}

In the present study, sweat $\mathrm{Zn}$ concentration was higher in the neutral than in the hot environmental conditions; however, when the sweat rates were included, the rate of $\mathrm{Zn}$ loss was similar for both exercise conditions. Even though the $\mathrm{Zn}$ concentration in the sweat of the males was similar to that in the females, male athletes had higher absolute $\mathrm{Zn}$ losses than female athletes, due to higher arm sweat rates, which in turn were probably due to larger arm surface areas. Wholebody $\mathrm{Zn}$ losses of males and females were not different when body surface area was considered.

To our knowledge, only one other study has reported $\mathrm{Zn}$ concentrations in the sweat of exercising subjects (2). The subjects (males) exercised at $21^{\circ} \mathrm{C}$ and concentrations of $0.45 \pm 0.48 \mu \mathrm{g} / \mathrm{ml}$ were reported. The male subjects in the present study had $\mathrm{Zn}$ values that were comparable at similar temperatures $(0.52$ $\pm 0.27 \mu \mathrm{g} / \mathrm{ml}$ ) to the previous values only during the second $30 \mathrm{~min}$ of exercise. 
266 / Tipton, Green, Haymes, and Waller
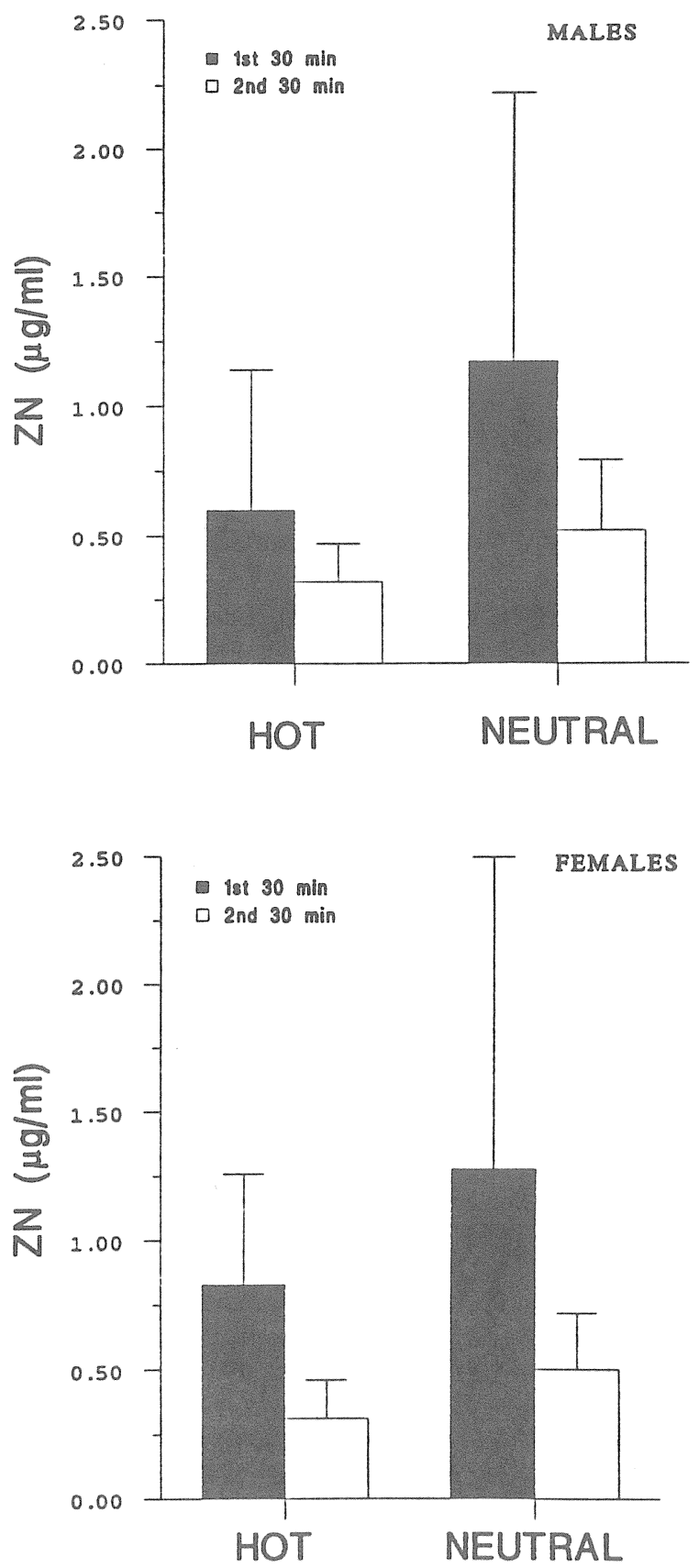

Figure 1 - Zinc concentration (mean $\pm S D$ ) from the first and second 30 -min periods of cycle ergometer exercise under hot $\left(35^{\circ} \mathrm{C}\right)$ and neutral $\left(25^{\circ} \mathrm{C}\right)$ conditions from male (top) and female (bottom) athletes. 

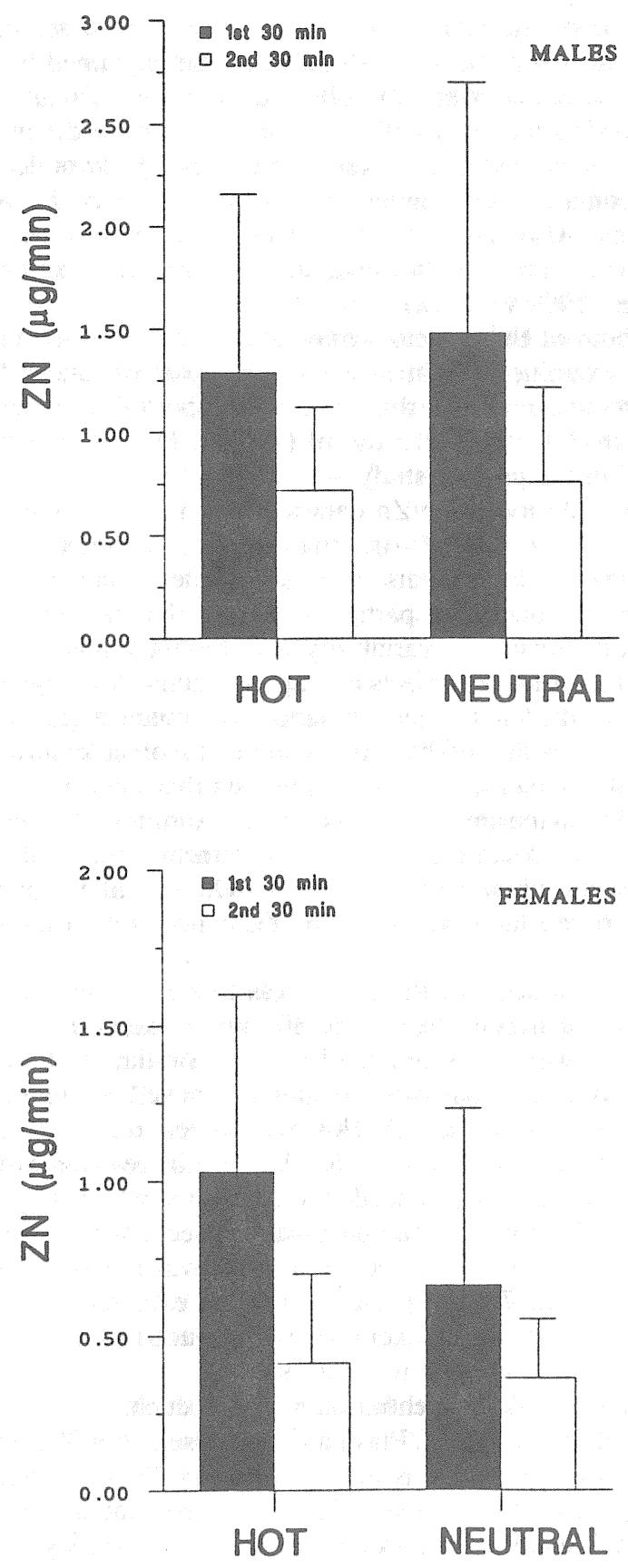

Figure 2 - Rate of zinc loss (mean $\pm S D$ ) from the first and second 30 -min periods of cycle ergometer exercise under hot $\left(35^{\circ} \mathrm{C}\right)$ and neutral $\left(25^{\circ} \mathrm{C}\right)$ conditions from male (top) and female (bottom) athletes. 
The first 30 min produced values that were over twice those reported by Arouma et al. (2). The discrepancy between studies may be explained by the method of sweat collection. Arouma et al. (2) collected sweat by manual scraping with a plastic tube following the 30 - to 40 -min exercise bout. In the present study the $\mathrm{Zn}$ concentration decreased as the exercise progressed. By collecting at the end of the bout, Arouma and colleagues (2) may have collected sweat with lower $\mathrm{Zn}$ concentrations. Also, Arouma et al. used a different technique for sweat collection, scraping with a plastic tube, and their subjects exercised at a higher intensity ( $80 \%$ vs. $50 \% \mathrm{VO}_{2} \max$ ).

Either or both of these factors may affect $\mathrm{Zn}$ concentration in sweat. No other study has examined $\mathrm{Zn}$ in sweat during exercise under hot conditions. However, the $\mathrm{Zn}$ concentrations that have been reported from subjects at rest in the heat ranged from 0.50 to $1.15 \mu \mathrm{g} / \mathrm{ml}(12,13,23,25)$, which are similar to the values found in the present study.

The high variability of the $\mathrm{Zn}$ data reported in the present study seems to be an important finding in itself. Arouma et al. (2) also reported high variation in $\mathrm{Zn}$ in the sweat of 12 subjects exercising. The variance of the $\mathrm{Zn}$ values reported for each of four body parts was higher than the means. Jacob et al. (13) compared the intrasubject variability with the intersubject variability of $\mathrm{Zn}$ concentration in the sweat of subjects resting in a sauna. Although the intrasubject variance was $48 \%$, the intersubject variance was much higher $(76 \%)$. While a $48 \%$ variance indicates that perhaps the methods involved contribute to the total variability, a $76 \%$ intersubject variance suggests that there is a large difference between individuals in the amount of $\mathrm{Zn}$ in sweat. Additionally, the low concentrations found in the sweat samples are near the detection limits of the spectrophotometer and may contribute to the variations. Other studies collecting sweat at rest also demonstrated large variances of $\mathrm{Zn}$ concentration among individuals $(12,25)$.

The $\mathrm{Zn}$ concentration of the sweat was twice as high during the first 30 min of exercise compared to the second $30 \mathrm{~min}$ of exercise. Sweat rates during the second $30 \mathrm{~min}$ were also higher (Table 2). Similar to the results reported here for $\mathrm{Zn}$, the concentrations of some minerals have been reported to decrease with increasing sweat rate $(6,28)$. However, other minerals were reported to increase $(6,28)$, or remain the same $(6,15)$, with increasing sweat flow. These data suggest that further study is needed to determine whether a $\mathrm{Zn}$ conservation mechanism exists. A long-term $\mathrm{Zn}$ conservation mechanism is suggested by data from Consolazio et al. (5). Zn collected in sweat was measured over 16 days of exposure to $37.8^{\circ} \mathrm{C}$ for 7.5 hrs per day. The $\mathrm{Zn}$ excreted during Days 1 to 4 averaged $13.70 \mathrm{mg}$, but the $\mathrm{Zn}$ excretion was reduced to an average of 2.16 to $2.41 \mathrm{mg}$ per day for the remaining 12 days.

Changes in sweat $\mathrm{Zn}$ concentration may reflect changes in the extracellular $\mathrm{Zn}$ concentration during exercise. Plasma $\mathrm{Zn}$ increased after 30 minutes of moderately heavy exercise (22), but was not significantly changed after running from 6 to 10 miles $(1,27)$. Ohno et al. (22) suggested that the initial rise in $\mathrm{Zn}$ may be due to mobilization from other tissues (e.g., erythrocytes). During more prolonged exercise it is possible that an acute phase response is stimulated and that $\mathrm{Zn}$ is removed by other organs. Unfortunately, changes in plasma $\mathrm{Zn}$ were not measured in this investigation.

Using the $\mathrm{Zn}$ concentrations from arm sweat and extrapolating to the whole 
body, the total estimated $\mathrm{Zn}$ loss for 1 hour of cycle exercise is about $0.65 \mathrm{mg}$ for males and $0.39 \mathrm{mg}$ for females. These values do not seem important when considered in view of the RDAs, $15 \mathrm{mg} /$ day for males and $12 \mathrm{mg} /$ day for females. However, Jacob et al. (13) reported that surface $\mathrm{Zn}$ losses ranged from 0.50 to $0.76 \mathrm{mg} / \mathrm{day}$, and Milne et al. (17) reported an average $\mathrm{Zn}$ loss of $0.49 \mathrm{mg} / \mathrm{day}$ in sedentary males. Therefore exercise at a moderate intensity for 1 hour may double the surface losses of $\mathrm{Zn}$. Total $\mathrm{Zn}$ loss per day has been estimated to range from 2.2 to $2.8 \mathrm{mg} /$ day in healthy, adequately nourished young men (3). Therefore, given the values found in this experiment, moderate intensity exercise may add an additional $23-30 \%$ to the total surface $\mathrm{Zn}$ loss in a day.

Zn concentrations in sweat may vary considerably between body parts (2), and even from one arm to the other (13); therefore care must be taken when extrapolating $\mathrm{Zn}$ concentrations from one body part to whole-body losses. However, there is still some indication that $\mathrm{Zn}$ excretion in sweat, especially if considered over repeated days of exercising in the heat, may be worth noting for athletes. The estimate of $\mathrm{Zn}$ loss during exercise is probably conservative since the $\mathrm{Zn}$ concentration of arm sweat is at the low end of the range reported from different body parts (2). Additionally, many athletes exercise for an hour at much higher intensities than in the present study, which would increase sweat rates and therefore $\mathrm{Zn}$ losses. The potential $\mathrm{Zn}$ losses from sweat combined with low $\mathrm{Zn}$ intakes $(8,24)$ may help explain the hypozincemia in athletes reported by Dressendorfer and Sockolov (9) and Haralambie (11).

These findings suggest that athletes, especially males, should be aware of potential $\mathrm{Zn}$ losses in sweat during training. Large individual variation in $\mathrm{Zn}$ losses seems to be a consistent result. The increased sweat rates that result from training under hot conditions may further exacerbate the loss of $\mathrm{Zn}$. Although Dressendorfer et al. (10) have shown that repeated days of prolonged running in the heat did not cause the development of a plasma $\mathrm{Zn}$ deficit in athletes who were eating a well-balanced diet, other studies have suggested that heavy training altered serum and erythrocyte $\mathrm{Zn}$ levels $(7,21)$. Couzy et al. (7) also suggested that any slight alteration in $\mathrm{Zn}$ status during intensive training may be offset by adequate $\mathrm{Zn}$ in the diet. Therefore, provided that athletes are aware of potential $\mathrm{Zn}$ losses during training and consume foods that are good sources of $\mathrm{Zn}, \mathrm{Zn}$ levels should not be appreciably altered by sweat losses during heavy training.

\section{References}

1. Anderson, R.A., M.M. Polansky, and N.A. Bryden. Acute effects on chromium, copper, zinc, and selected clinical variables in urine and serum of male runners. Biol. Trace Element Res. 6:327-336, 1984.

2. Arouma, O.I., T. Reilly, D. MacLaren, and B. Halliwell. Iron, copper, and zinc concentrations in human sweat and plasma; The effects of exercise. Clin. Chem. 177:81-88, 1988.

3. Baer, M.T., and J.C. King. Tissue levels and zinc excretion during experimental zinc depletion in young men. Am. J. Clin. Nutr. 39:556-570, 1984.

4. Collins, K.J., and J.S. Weiner. Observations on arm-bag suppression of sweating and its relationship to thermal sweat gland 'fatigue'. J. Physiol. (London) 161:538-556, 1962.

5. Consolazio, C.F., R.A. Nelson, L.R.O. Matoush, and R.C. Hughes. The Trace Mineral 
Losses in Sweat. Denver: U.S. Army Medical Research and Nutrition Laboratory, Report No. 284, 1964.

6. Costill, D.L. Sweating: Its composition and effects on body fluids. Annals N.Y. Acad. Sci. 301:160-174, 1977.

7. Couzy, F., P. LaFargue, and C.Y. Guezennec. Zinc metabolism in the athlete: Influence of training, nutrition and other factors. Int. J. Sports Nutr. 11:263-266, 1990.

8. Deuster, P.A., B.A. Day, A. Singh, L. Douglass, and P.B. Moser-Veillon. Zinc status of highly trained women runners and untrained women. Am. J. Clin. Nutr. 49:12951301, 1989.

9. Dressendorfer, R.H., and R. Sockolov. Hypozincemia in runners. Phys. Sportsmed. 8(4):97-100, 1980.

10. Dressendorfer, R.H., C.E. Wade, C.L. Keen, and J.H. Scaff. Plasma mineral levels in marathon runners during a 20-day road race. Phys. Sportsmed. 10(6):113-118, 1982.

11. Haralambie, G. Serum zinc in athletes in training. Int. J. Sports Med. 2:135-138, 1981.

12. Hohnadel, D.C., F.W. Sunderman, Jr., M.W. Nechay, and M.D. McNeely. Atomic absorption spectrometry of nickel, copper, zinc, and lead in sweat collected from healthy subjects during sauna bathing. Clin. Chem. 19:1288-1292, 1973.

13. Jacob, R.A., H.H. Sandstead, J.M. Munoz, L.M. Klevay, and D.B. Milne. Whole body surface loss of trace metals in normal males. Am. J. Clin. Nutr. 34:1379-1383, 1983.

14. Keilin, D., and T. Mann. Carbonic anhydrase. Nature 144:442-443, 1939.

15. Kobayashi, Y., Y. Ando, S. Takeuchi, K. Takemura, N. Okuda, Y. Isobe, S. Takaba, and $\mathrm{K}$. Ohara. Effects of heat acclimation of distance runners in a moderately hot environment. Eur. J. Appl. Physiol. 45:189-198, 1980.

16. McArdle, W., F. Katch, and G. Peschar. Comparison of continuous and discontinuous treadmill and bicycle tests for max $\mathrm{VO}_{2}$. Med. Sci. Sports Exerc. 5:156-160, 1973.

17. Milne, D.B., W.K. Canfield, J.R. Mahalko, and H.H. Sandstead. Effect of dietary zinc on whole body surface loss of zinc: Impact on estimation of zinc retention by balance method. Am. J. Clin. Nutr. 38:181-186, 1983.

18. Miyamura, J.B., S.W. McNutt, and N.S. Wenkam. Altered zinc status of soldiers under field conditions. J. Am. Diet. Assoc. 87:595-597, 1987.

19. Nadel, E.R., J.W. Mitchell, and J.A.J. Stolwijk. Control of local and total sweating during exercise transients. Int. J. Biometr. 15:201-206, 1971.

20. Nadel, E.R., K.B. Pandolf, M.F. Roberts, and J.A.J. Stolwijk. Mechanisms of thermal acclimation to exercise and heat. J. Appl. Physiol. 37:515-520, 1974.

21. Ohno, H., Y. Sato, M. Ishikawa, T. Yahata, S. Gusa, R. Doi, K. Yamamura, and N. Taniguchi. Training effects on blood zinc levels in humans. J. Sportsmed. Phys. Fit. 30:247-253, 1990.

22. Ohno, H., K. Yamashita, R. Doi, K. Yamamura, T. Konda, and N. Taniguchi. Exerciseinduced changes in blood zinc and related proteins in humans. J. Appl. Physiol. 58:1453-1458, 1985.

23. Prasad, A.S., A.R. Schulert, H.H. Sandstead, A. Miale, Jr., and Z. Farid. Zinc, iron and nitrogen content of sweat in normal and deficient subjects. J. Lab. Clin. Med. 62:84-89, 1963.

24. Singh, A., P.A. Deuster, and P.B. Moser. Zinc and copper status of women by physical and menstrual status. J. Sports Med. Phys. Fit. 30:29-36, 1990. 
25. Stauber, J.L., and T.M. Florence. A comparative study of copper, lead, cadmium and zinc in human sweat and blood. Sci. Tot. Environ. 74:235-247, 1988.

26. Vallee, B.L. Zinc in biology and biochemistry. In Zinc Enzymes, T.G. Spiro (Ed.), New York: Wiley \& Sons, 1983, pp. 1-24.

27. Van Rij, A.M., M.T. Hall, G.L. Dohm, J. Bray, and W.J. Pories. Changes in zinc metabolism following exercise in human subjects. Biol. Trace Element Res. 10:99$105,1986$.

28. Verde, T., R.J. Shephard, P. Corey, and R. Moore. Sweat composition in exercise and in heat. J. Appl. Physiol. 53:1540-1545, 1982.

\section{XXVth FIMS World Congress of Sports Medicine "Sports and Medicine for a Healthier Life" Athens, Greece, September 10-16, 1994}

Official languages: Greek, English, and French. Abstracts and papers should be presented in English. Proceedings of the Congress will be published in English.

Topics: Sports traumatology; Sport sociology; Sport psychology; Biomechanics and kinesiology; Rehabilitation and physical therapy; Sport for the disabled; Physiology, cardiovascular and pulmonary; Physical conditioning; Sport nutrition; Biochemistry and molecular biology.

Registration fee: $\$ 350$ U.S. before May 31, 1994; $\$ 400$ after that date

For more information, contact

Congress Bureau "Organization Idea"

c/o Mania Bessieri, Congress Manager

24 Voulis str., 10563 Athens, Greece

Tel: +301/324 $2045 ; \quad$ Fax: +301 3221023 